\title{
Uusioersily
}

\section{Micronutrient supplementation in maintenance haemodialysis patients enhances activity of antioxidant enzymes.}

Hannon-Fletcher, M. P. A., Garrett, P., \& Moffitt, T. (2012). Micronutrient supplementation in maintenance haemodialysis patients enhances activity of antioxidant enzymes. Journal of Nephrology, 29. https://doi.org/10.5301/jn.5000135

Link to publication record in Ulster University Research Portal

\section{Published in:}

Journal of Nephrology

Publication Status:

Published (in print/issue): 01/05/2012

DOI:

10.5301/jn.5000135

\section{Document Version}

Publisher's PDF, also known as Version of record

\section{General rights}

Copyright for the publications made accessible via Ulster University's Research Portal is retained by the author(s) and / or other copyright owners and it is a condition of accessing these publications that users recognise and abide by the legal requirements associated with these rights.

\section{Take down policy}

The Research Portal is Ulster University's institutional repository that provides access to Ulster's research outputs. Every effort has been made to ensure that content in the Research Portal does not infringe any person's rights, or applicable UK laws. If you discover content in the Research Portal that you believe breaches copyright or violates any law, please contact pure-support@ulster.ac.uk. 


\section{Journal of Nephrology \\ Micronutrient supplementation in maintenance haemodialysis patients enhances activity of antioxidant enzymes. \\ --Manuscript Draft--}

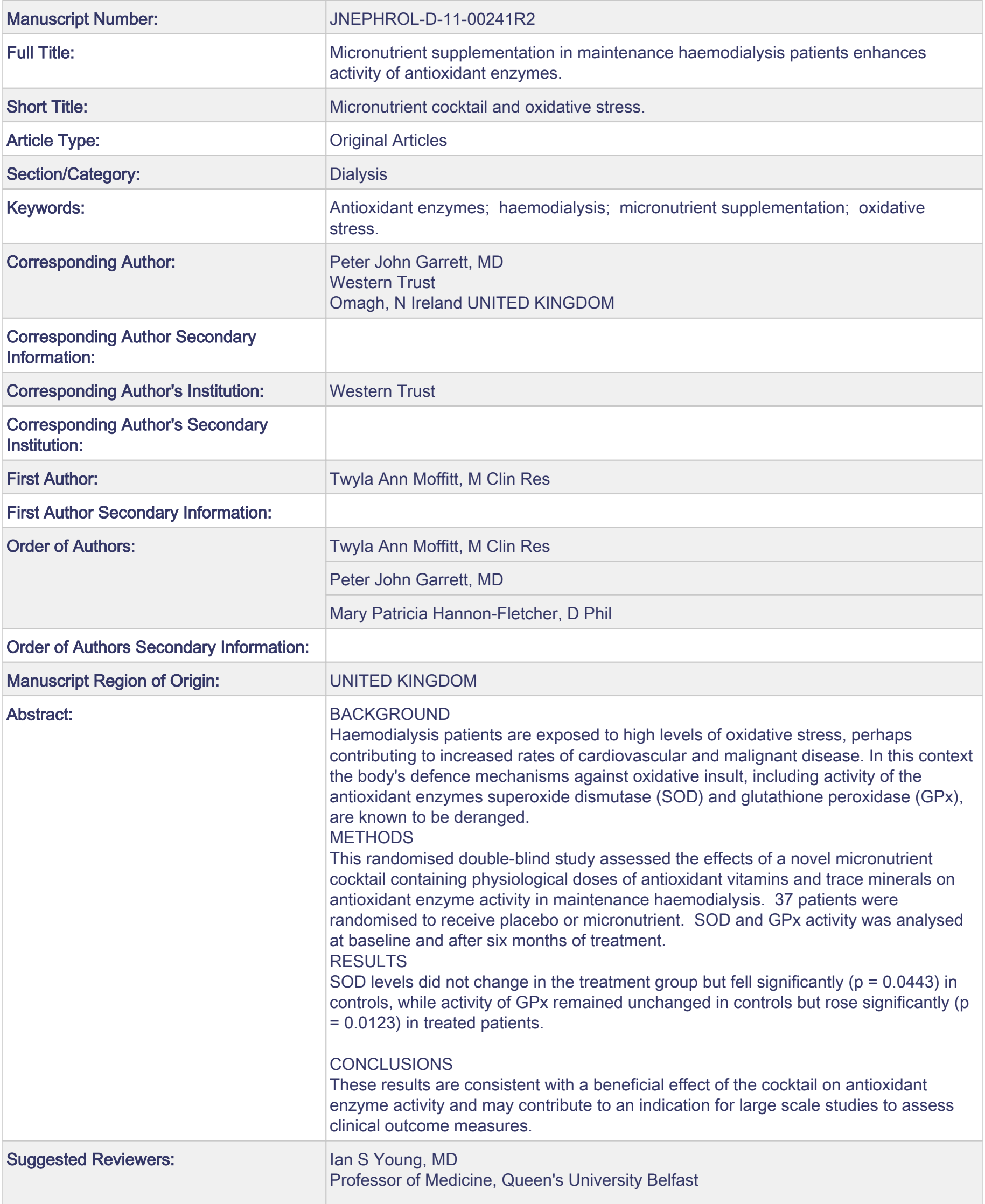


i.young@qub.ac.uk

Research interests in oxidative stress and vitamins.

A Peter Maxwell, MD

Professor of Nephrology, Queen's University Belfast

peter.maxwell@belfasttrust.hscni.net

Research publications on antioxidant enzymes in dialysis.

Opposed Reviewers: 


\section{Micronutrient supplementation in maintenance haemodialysis patients enhances activity of antioxidant enzymes.}

\section{SHORT TITLE}

Micronutrient cocktail and oxidative stress.

\section{AUTHORS}

Twyla A Moffitt ${ }^{1}$

Peter J Garrett ${ }^{1}$

Mary P Hannon-Fletcher ${ }^{2}$

${ }^{1}$ Western Renal Service, Tyrone County Hospital, Omagh and Altnagelvin

Hospital, Derry/Londonderry

${ }^{2}$ Northern Ireland Centre for Food and Health, Biomedical Sciences Research

Institute, University of Ulster, Coleraine

Northern Ireland, United Kingdom. 


\section{CORRESPONDING AUTHOR}

Peter J Garrett MD

Renal Unit

Tyrone County Hospital

Hospital Road

Omagh

BT79 OAP

Northern Ireland

Telephone: $+44(0) 2882833520$

Fax: $+44(0) 2882833563$

peter.garrett@westerntrust.hscni.net

\section{DISCLOSURES}

The authors confirm that the manuscript has been seen and approved by all authors and that it is not under consideration for publication elsewhere in a similar form, in any language, except in abstract form.

This study was supported by an Amgen / Irish Nephrological Society Research Bursary.

No conflicts of interest to declare. 


\section{ABSTRACT}

\section{BACKGROUND}

Haemodialysis patients are exposed to high levels of oxidative stress, perhaps contributing to increased rates of cardiovascular and malignant disease. In this context the body's defence mechanisms against oxidative insult, including activity of the antioxidant enzymes superoxide dismutase (SOD) and glutathione peroxidase (GPx), are known to be deranged.

\section{METHODS}

This randomised double-blind study assessed the effects of a novel micronutrient cocktail containing physiological doses of antioxidant vitamins and trace minerals on antioxidant enzyme activity in maintenance haemodialysis. 37 patients were randomised to receive placebo or micronutrient. SOD and GPx activity was analysed at baseline and after six months of treatment.

\section{RESULTS}

SOD levels did not change in the treatment group but fell significantly $(p=$ 0.0443) in controls, while activity of GPx remained unchanged in controls but rose significantly $(p=0.0123)$ in treated patients. 


\section{CONCLUSIONS}

These results are consistent with a beneficial effect of the cocktail on antioxidant

enzyme activity and may contribute to an indication for large scale studies to assess clinical outcome measures.

\section{KEYWORDS}

Antioxidant enzymes; haemodialysis; micronutrient supplementation; oxidative stress. 


\section{INTRODUCTION}

Haemodialysis patients have a much lower survival than the general population (1), with a huge excess cardiovascular mortality (2) and higher rates of cancer

(3). Antioxidant status is disordered in chronic kidney disease (4) and haemodialysis itself promotes further oxidant insult (5). Markers of oxidative stress are higher in haemodialysis patients with as opposed to without cardiovascular disease (6), and perhaps oxidative damage to cellular macromolecules contributes to the amplified risk of cardiovascular and neoplastic disorders.

The organism's defence against oxidative stress includes the antioxidant enzymes superoxide dismutase (SOD) and glutathione peroxidase (GPx). Both these enzymes are known to be disordered in chronic kidney disease (7-10). Possible mechanisms include increased stimulation or exhaustion of enzyme systems by overwhelming oxidative challenge, altered expression of messenger RNA $(11,12)$, loss of renal functioning mass with reduction in synthetic capacity (13), and depletion of antioxidant vitamins or essential trace elements such as copper, zinc and selenium $(8,14)$ because of inadequate intake or excess removal by dialysis.

To investigate whether replenishment of physiological doses of trace elements and antioxidant vitamins could ameliorate this enzyme derangement, we studied the effects of a micronutrient cocktail (MNC) on SOD and GPx activity in maintenance haemodialysis patients. 


\section{SUBJECTS AND METHODS}

The study received full ethical approval from the Office of Research Ethics Committees of Northern Ireland (ORECNI) and was conducted in adherence with the Declaration of Helsinki.

Adult subjects were recruited by interview, detailed information leaflet and signed informed consent from the haemodialysis populations programmes at Tyrone County Hospital, Omagh, and Altnagelvin Hospital, Derry/Londonderry, Northern Ireland. Exclusion criteria are shown in Table 1. 39 subjects in total were enrolled in the study.

All patients received thrice weekly haemodialysis against biocompatible membranes with the dialysis prescription adjusted to deliver a Kt/V of 1.2 or higher. All received erythropoesis stimulating agents (epoetin alfa or darbepoetin alfa) to maintain haemoglobin according to Renal Association standards. Renal Association targets for calcium, phosphate and parathyroid hormone were maintained with phosphate binders and vitamin D analogues and, where required, cinacalcet according to NICE guidelines. Low dose parenteral iron was administered to maintain transferrin saturation $>20 \%$.

Subjects were randomised to receive a daily capsule containing the micronutritional cocktail (MNC) or placebo. The composition of the MNC is shown in Table 2 and is based on published recommended daily allowances in 
the United Kingdom (15). Doses of water soluble vitamins were adjusted slightly to take account of losses during haemodialysis. The dose of folate was lower than these recommendations and based on published evidence of the quantity required to reduce plasma homocysteine levels (16). The dose of vitamin B12, on the other hand, was increased to avoid any risk of B12 deficiency neuropathy in the context of folate supplementation.

Concordance with medication was checked by monthly interviews and tablet counts. Clinical events were logged in the electronic patient record.

Clotted and whole blood samples (lithium heparin) were drawn predialysis at baseline, three months and six months. Serum and plasma were separated immediately and stored frozen at $-70^{\circ} \mathrm{C}$ before analysis. SOD and GPx concentrations in red cells separated from lithium heparin samples were determined on the ILab650 analyser using commercially available kits from Randox Laboratories, Antrim, UK.

Group means were compared by paired or unpaired Student's t-test as appropriate or, for non-normally distributed data, by the Wilcoxon rank sum test. Differences in proportions were tested by chi-square or Fisher's exact test for parametric and non-parametric data respectively. 


\section{RESULTS}

37 of the 39 subjects enrolled into the study were randomised. Serum phosphate was slightly lower in the placebo arm (1.25 versus $1.49 \mathrm{mmol} / \mathrm{l}, \mathrm{p}=0.0094)$, but baseline demographic, clinical, laboratory and therapeutic features, folic acid status and total antioxidant capacity as measured by the Ferric Reducing Ability of Plasma (FRAP) assay otherwise did not differ between the groups (Tables 3a and 3b). The placebo arm lost three subjects and the intervention arm four before completion. 30 subjects (14 in the intervention group and 16 in the placebo group) completed the study.

Baseline levels of SOD (1207 iu/gHb +/- 143.1 vs $1271+/-163.1 ; p=0.7739)$ and GPx (79.82 +/- 10.65 vs $68.97 \pm 5.934 ; \mathrm{p}=0.3655)$ (Figure 1) did not differ between the groups. Neither enzyme was influenced by age, gender, diabetes status, time since first dialysis, time since first renal presentation, or delivered dose of dialysis as Kt/V. Mean baseline SOD (1241) was close to the lower limit of the population reference range $(1102-1601)$. Twelve of thirty subjects fell below the range.

SOD in control subjects showed a further significant fall six months after initiation of the study (1271 vs $880.9, \mathrm{p}=0.0443$ ) (Figure 2). SOD in the intervention group, on the other hand, remained unchanged over the same period (1207 vs $1062, p=0.3083$ ). After six months, SOD levels in control subjects tended to be lower than in the treated group (880.9 vs $1062, p=$ 0.0688). 
Baseline GPx, by contrast, tended to be higher (mean $74.03 \mathrm{iu} / \mathrm{gHb}$ ) (Figure 3) than the population range (30-55), with 23 of 30 samples above the upper limit and only 7 lying within range.

GPx activity in the control group did not change during the study (68.97 vs 79.78, $\mathrm{p}=0.1546$ ) (Figure 4). In the intervention group, however, GPx rose significantly from a mean of 79.82 to $134.60(p=0.0123)$. After six months, GPx activity in the intervention group were highly significantly greater than in the control group (134.60 vs 79.78, $\mathrm{p}=0.0001)$. 


\section{DISCUSSION}

Antioxidant enzymes form a crucial part of the body's defence against oxidative damage. Superoxide dismutase (SOD) is a suite of three enzymes responsible for catalyzing the dismutation of superoxide radicals into molecular oxygen and hydrogen peroxide. SOD3 is extracellular; the intracellular enzymes are soluble SOD1 in the cytoplasm and mitochondria, and mitochondrial SOD2. SOD1 is a homodimer binding copper and zinc and encoded by a gene at position 22.1 on the long arm of chromosome 21 . SOD1 knockout mice display exaggerated agerelated loss of muscle mass (17) and an increased frequency of hepatocellular carcinoma (18). The homotetramer SOD2, genetically encoded at locus 6q25, contains manganese; lack of this enzyme in mice is fatal within a few days of birth (19).

Glutathione peroxidise (GPx) is a family of eight enzymes acting downstream from SOD to reduce free hydrogen peroxide to water. The most abundant isoform is GPx1, a homotetramer containing selenium and encoded at 3p21.3. GPx1 knockout mice exhibit early development of cataracts (17).

Although there is considerable variation in reported results (20-26), our findings are consistent with many previous studies showing that SOD activity is reduced in renal failure (7-10, 27-29). This may reflect exhaustion of the enzyme system by exaggerated oxidant stress as well as low copper and zinc reserves (8) related to both dietary deficiency and increased losses across dialysis. The maintenance of SOD levels in our intervention subjects, in contrast to the placebo group, suggests a beneficial effect of the micronutrient supplement on the enzyme 
system, either by replenishing exhausted trace metal reserves or by a general amelioration of oxidative stress.

By contrast, GPx activity in our subjects tended to be higher than in the general population. It may be that the GPx system had been upregulated in our patients to combat the increased levels of oxidative stress associated with uraemia and dialysis but, as a second line of defence, had not yet become exhausted. The significant increase in enzyme activity in the treated but not the placebo group once more supports a beneficial effect of the supplement.

Why however should GPx activity in our subjects be higher than in the general population, whereas levels in dialysis patients in most previous publications have tended to be low $(5,8,10,14,24-28,30,31)$ ? These papers include a study in Belfast (5) on a group of patients that, other than containing a higher proportion of urban dwellers, would have been constitutionally and environmentally very similar to our population.

The answer is almost certainly evident within the detailed description of the subjects in the Belfast study. These patients dialysed twice weekly against nonbiocompatible cellulosic membranes. This was in an era before quality control of dialysis adequacy by Kt/V was commonplace and nutritional support for dialysis patients may also have been less advanced. In contrast, the patients in the current study were on at least thrice weekly dialysis against biocompatible membranes with careful monitoring of dialysis adequacy and regular specialist nutritional assessment. It is therefore likely that their exposure to oxidative stress, caused by both uraemia and by non-compatible dialysis membranes, was less than the Belfast cohort and probable that their nutritional reserves of trace 
metals and anti-oxidant vitamins were greater. Thus the discrepancy in baseline GPx activity is entirely comprehensible.

We believe that the most likely explanation for the further increase in GPx activity after micronutrient supplementation represents an improvement in the ability of the enzyme system to combat continuing oxidative stress, possibly because of supplementation of nutrients essential for the system, including selenium. We consider the alternative hypothesis, that the enhanced activity (in the context of supplementation of antioxidant agents) reflects an increase in oxidative stress to be counterintuitive and, since SOD activity was maintained in the active but not in the placebo group, to be less likely. We have not as yet been able to measure selenium levels to provide support for this explanation.

Total antioxidant capacity by FRAP assay at the start of the study was identical between the active and control groups. We intend to derive additional information by measuring lipid peroxidation, but this has not yet been performed. We also plan to measure oxidative DNA damage using a modified COMET assay and will report these results separately.

The literature on controlled trials of the effects of dietary modification on oxidant stress in haemodialysis is limited. Supplementation with folic acid reduces homocysteine levels, in turn a risk factor for cardiovascular disease in haemodialysis patients, as well as improving plasma total antioxidant capacity (32). An open study of folate administration has claimed a beneficial effect (33), but results with vitamin B group supplementation have usually been disappointing: high doses of thiamine and pyridoxine did not ameliorate markers of oxidative stress (34) and folic acid alone (35) or with other B vitamins $(36,37)$ has not improved cardiovascular outcome (although the doses of folate used 
were much higher than in the current study). Combination of folate and other B vitamins with vitamins $\mathrm{E}$ and $\mathrm{C}(38)$ has also failed to reduce markers of oxidative stress.

Administration of vitamin $\mathrm{C}$ alone to haemodialysis patients increases serum ascorbate levels (38) with potentially beneficial effects on malondialdehyde and lipid levels (40) and on plasma polypeptide characteristics (41). A randomized open-label trial did not however show any benefit on inflammation or oxidative stress (42). Intravenous ascorbate does seem to reduce intracellular production of reactive oxygen species (43) and has been combined with use of vitamin E coated dialysis membranes to enhance this effect (44).

Indeed, several small studies (45-47) have suggested benefit from vitamin E coated dialysis membranes on various markers of oxidative damage. A small randomised study (48) of oral supplementation with vitamin E confirmed changes in serum alfa- and gamma-tocopherol levels but was insufficiently powered to demonstrate amelioration of oxidative protein modifications. Another recent trial (49) has shown that both oral vitamin E and concentrated red grape juice (containing polyphenols) reduce levels of oxidised low density lipoprotein and neutrophil NADPH oxidase activity and that this effect is amplified by these agents in combination.

Although a further study of oral vitamin $E$ has not shown any benefit on markers of microinflammation (50), a large controlled trial in haemodialysis patients with prevalent cardiovascular disease has demonstrated a reduction in composite cardiovascular endpoints and myocardial infarction (51). Similar results have been reported for antioxidant therapy with acetylcysteine (52). 
In conclusion, although the data remain relatively scant, there is emerging evidence that anti-oxidant therapy may improve clinical outcomes as well as laboratory markers of oxidative stress. The effects of a combination of physiological doses of antioxidant vitamins and trace elements have not been described previously, and the potential of this simple intervention deserves further evaluation. This carefully controlled and blinded study has demonstrated clearly significant effects of a unique combined micronutritional supplement on activity of anti-oxidant enzymes. These results are consistent with an interpretation that the supplement supports enzyme systems in resisting oxidant stress and may provide support for further studies to determine whether this observation can be translated into clinical benefit for haemodialysis patients. 


\section{REFERENCES}

1) Ansell $D$, Roderick $P$, Steenkamp R, Tomson CR.

UK Renal Registry 12th Annual Report (December 2009): Chapter 7: Survival and causes of death of UK adult patients on renal replacement therapy in 2008: national and centre-specific analyses.

Nephron Clin Pract. 2010; 115 Suppl 1: c117-44.

2) Gurland HJ, Brunner FP, Dehn H, Harlen H, Parsons FM, Scharer K. Combined report on regular dialysis and transplantation in Europe, III, 1972.

Proc Eur Dial Transplant Assoc. 1973; 10: XVII-LVII.

3) Matas AJ, Simmons RL, Kjellstrand CM, Buselmeier TJ, Najarian JS. Increased incidence of malignancy during chronic renal failure. Lancet. 1975; 1(7912): 883-886.

4) Kuroda M, Asaka S, Tofuku Y, Takeda R.

Serum antioxidant activity in uremic patients.

Nephron. 1985; 41: 293-298.

5) Loughrey CM, Young IS, Lightbody JH, McMaster D, McNamee PT, Trimble ER.

Oxidative stress in haemodialysis.

QJM. 1994; 87: 679-683. 
6) Dirican M, Sarandol E, Serdar Z, Ocak N, Dilek K.

Oxidative status and prevalent cardiovascular disease in patients with chronic renal failure treated by hemodialysis.

Clin Nephrol. 2007; 68: 144-150

7) Shainkin-Kestenbaum R, Caruso C, Berlyne GM.

Reduced superoxide dismutase activity in erythrocytes of dialysis patients:

a possible factor in the etiology of uremic anemia.

Nephron. 1990; 55: 251-253

8) Richard MJ, Arnaud J, Jurkovitz C, et al.

Trace elements and lipid peroxidation abnormalities in patients with chronic renal failure.

Nephron. 1991; 57: 10-15

9) Steiner M, von Appen K, Klinkmann H, Ernst B.

Superoxide dismutase activity and lipid peroxidation products in patients with chronic renal failure on maintenance haemodialysis.

Nephrol Dial Transplant. 1992; 7: 368-369.

10) Shurtz-Swirski R, Mashiach E, Kristal B, Shkolnik T, Shasha SM.

Antioxidant enzymes activity in polymorphonuclear leukocytes in chronic renal failure.

Nephron. 1995; 71: 176-179.

11) Vaziri ND, Dicus M, Ho ND, Boroujerdi-Rad L, Sindhu RK.

Oxidative stress and dysregulation of superoxide dismutase and NADPH

oxidase in renal insufficiency.

Kidney Int. 2003; 63: 179-185. 
12) Akiyama $S$, Inagaki $M$, Tsuji $M$, et al.

mRNA study on $\mathrm{Cu} / \mathrm{Zn}$ superoxide dismutase induction by hemodialysis treatment.

Nephron Clin Pract. 2005; 99: c107-114.

13) Avissar N, Ornt DB, Yagil $Y$ et al.

Human kidney proximal tubules are the main source of plasma glutathione peroxidase.

Am J Physiol. 1994; 266: C367-375.

14) Girelli $D$, Olivieri $O$, Stanzial $A M$ et al.

Low platelet glutathione peroxidase activity and serum selenium

concentration in patients with chronic renal failure: relations to dialysis

treatments, diet and cardiovascular complications.

Clin Sci (Lond). 1993; 84: 611-617.

15) Dietary reference values for food energy and nutrient intake for the United Kingdom. Report of the Panel on Dietary Reference Values of the Committee on Medical Aspects of Food Policy. Rep Health Soc Subj (Lond), 1991.

16) Variese AS, Verbeke $F$, Schrijvers $B F$, Lamiere $\mathrm{NH}$. Is folate a promising agent in the prevention and treatment of cardiovascular disease in patients with renal failure? Kidney Int 2002; 61: 1199-1209. 
17) Muller FL, Lustgarten MS, Jang $Y$, Richardson $A$, Van Remmen $H$.

Trends in oxidative aging theories.

18) Elchuri S, Oberley TD, Qi W, et al.

CuZnSOD deficiency leads to persistent and widespread oxidative damage and hepatocarcinogenesis later in life.

Oncogene. 2005; 24: 367-380.

19) Li Y, Huang TT, Carlson EJ, et al.

Dilated cardiomyopathy and neonatal lethality in mutant mice lacking manganese superoxide dismutase.

Nat Genet. 1995; 11: 376-381.

20) Chauhan DP, Gupta PH, Nampoothiri MR, Singhal PC, Chugh KS, Nair CR. Determination of erythrocyte superoxide dismutase, catalase, glucose-6phosphate dehydrogenase, reduced glutathione and malonyldialdehyde in uremia. Clin Chim Acta. 1982; 123: 153-159.

21) Trznadel K, Pawlicki L, Kedziora J, Luciak M, Blaszczyk J, Buczynski A. Superoxide anion generation, erythrocyte superoxide dismutase activity, and lipid peroxidation during hemoperfusion and hemodialysis in chronic uremic patients. Free Radic Biol Med. 1989; 6: 393-397

22) Toborek M, Wasik T, Drózdz M, Klin M, Magner-Wróbel K, KopiecznaGrzebieniak E.

Effect of hemodialysis on lipid peroxidation and antioxidant system in patients with chronic renal failure. 
Metabolism. 1992; 41: 1229-1232

23) Senol E, Ersoy A, Erdinc S, Sarandol E, Yurtkuran M. Oxidative stress and ferritin levels in haemodialysis patients. Nephrol Dial Transplant. 2008; 23: 665-672. PMID: 18039638 [PubMed - indexed for MEDLINE]

24) Schettler V, Wieland $E$, Methe $H$, Schuff-Werner $P$, Müller GA. Oxidative stress during dialysis: effect on free radical scavenging enzyme (FRSE) activities and glutathione (GSH) concentration in granulocytes. Nephrol Dial Transplant. 1998; 13: 2588-2593.

25) Lim PS, Wei $Y H, Y u Y L$, Kho B.

Enhanced oxidative stress in haemodialysis patients receiving intravenous iron therapy.

Nephrol Dial Transplant. 1999; 14: 2680-2687. PMID: 10534512 [PubMed indexed for MEDLINE]

26) Mimić-Oka J, Simić T, Djukanović L, Reljić $Z$, Davicević $Z$.

Alteration in plasma antioxidant capacity in various degrees of chronic renal failure.

Clin Nephrol .1999; 51: 233-241.

27) Zima T, Stípek S, Crkovská J, et al.

Antioxidant enzymes--superoxide dismutase and glutathione peroxidase--in haemodialyzed patients.

Blood Purif. 1996; 14: 257-61. PMID: 8738540 [PubMed - indexed for MEDLINE] 
28)

Dursun B, Dursun E, Suleymanlar G, et al.

Carotid artery intima-media thickness correlates with oxidative stress in chronic haemodialysis patients with accelerated atherosclerosis.

Nephrol Dial Transplant. 2008; 23: 1697-1703. PMID: 18174265 [PubMed indexed for MEDLINE]

29) Monostori P, Hracskó Z, Karg E, et al.

Erythropoiesis-stimulating agent withdrawal and oxidative stress in hemodialysis. Clin Nephrol. 2009; 71: 521-526. PMID: 19473612 [PubMed - indexed for MEDLINE]

30) Roxborough HE, Mercer C, McMaster D, Maxwell AP, Young IS.

Plasma glutathione peroxidase activity is reduced in haemodialysis patients. Nephron. 1999; 81: 278-283. PMID: 10050081 [PubMed - indexed for MEDLINE] 31) Weinstein $T$, Chagnac A, Korzets $A$, et al. Haemolysis in haemodialysis patients: evidence for impaired defence mechanisms against oxidative stress.

Nephrol Dial Transplant. 2000; 15: 883-887. PMID: 10831646 [PubMed - indexed for MEDLINE]

32) Alvares Delfino VD, de Andrade Vianna AC, Mocelin AJ, Barbosa DS, Mise RA, Matsuo $T$.

Folic acid therapy reduces plasma homocysteine levels and improves plasma antioxidant capacity in hemodialysis patients.

Nutrition. 2007; 23: 242-247. 
33) Righetti $M$, Serbelloni $P$, Milani $S$, Ferrario G.

Homocysteine-lowering vitamin B treatment decreases cardiovascular events in hemodialysis patients.

Blood Purif. 2006; 24: 379-386.

34) Nascimento MM, Suliman ME, Murayama $Y$, et al.

Effect of high-dose thiamine and pyridoxine on advanced glycation end products and other oxidative stress markers in hemodialysis patients: a randomized placebo-controlled study.

J Ren Nutr. 2006; 16: 119-124.

35) Wrone EM, Hornberger JM, Zehnder JL, McCann LM, Coplon NS, Fortmann SP.

Randomized trial of folic acid for prevention of cardiovascular events in end-stage renal disease.

J Am Soc Nephrol. 2004; 15: 420-426.

36) Heinz J, Kropf S, Domröse U, et al.

$B$ vitamins and the risk of total mortality and cardiovascular disease in end-stage renal disease: results of a randomized controlled trial.

Circulation. 2010; 121: 1432-1438.

37) Jamison RL, Hartigan $P$, Kaufman JS, et al.

Effect of homocysteine lowering on mortality and vascular disease in advanced chronic kidney disease and end-stage renal disease: a randomized controlled trial.

J Am Med Assoc. 2007; 298: 1163-1170. 
38) Kamgar M, Zaldivar F, Vaziri ND, Pahl MV.

Antioxidant therapy does not ameliorate oxidative stress and inflammation in patients with end-stage renal disease.

J Natl Med Assoc. 2009; 101: 336-344.

39) Washio $K$, Inagaki $M$, Tsuji $M$, et al.

Oral vitamin C supplementation in hemodialysis patients and its effect on the plasma level of oxidized ascorbic acid and Cu/Zn superoxide dismutase, an oxidative stress marker. Nephron Clin Pract. 2008; 109: c49-54.

40) Abdollahzad H, Eghtesadi S, Nourmohammadi I, Khadem-Ansari M, NejadGashti H, Esmaillzadeh A.

Effect of vitamin C supplementation on oxidative stress and lipid profiles in hemodialysis patients.

Int J Vitam Nutr Res. 2009; 79: 281-287.

41) Weissinger EM, Nguyen-Khoa T, Fumeron $C$, et al.

Effects of oral vitamin C supplementation in hemodialysis patients: a proteomic assessment.

Proteomics 2006; 6: 993-1000.

42) Fumeron $C$, Nguyen-Khoa $T$, Saltiel $C$, et al. Effects of oral vitamin $\mathrm{C}$ supplementation on oxidative stress and inflammation status in haemodialysis patients.

Nephrol Dial Transplant. 2005; 20: 1874-1879. 
43) Tarng DC, Liu TY, Huang TP.

Protective effect of vitamin C on 8-hydroxy-2'-deoxyguanosine level in peripheral blood lymphocytes of chronic hemodialysis patients.

Kidney Int. 2004; 66: 820-831.

44) Yang CC, Hsu SP, Wu MS, Hsu SM, Chien CT.

Effects of vitamin C infusion and vitamin E-coated membrane on hemodialysisinduced oxidative stress.

Kidney Int. 2006; 69: 706-714.

45) Clermont G, Lecour S, Cabanne JF et al.

Vitamin E-coated dialyzer reduces oxidative stress in hemodialysis patients. Free Radic Biol Med. 2001; 31: 233-241.

46) Tsuruoka S, Kawaguchi A, Nishiki K, et al.

Vitamin E-bonded hemodialyzer improves neutrophil function and oxidative stress in patients with end-stage renal failure.

Am J Kidney Dis. 2002; 39: 127-133.

47) Morimoto $H$, Nakao $K$, Fukuoka $K$, et al.

Long-term use of vitamin E-coated polysulfone membrane reduces oxidative stress markers in haemodialysis patients.

Nephrol Dial Transplant. 2005; 20: 2775-2782.

48) Lu L, Erhard P, Salomon RG, Weiss MF.

Serum vitamin $\mathrm{E}$ and oxidative protein modification in hemodialysis: a randomized clinical trial.

Am J Kidney Dis. 2007; 50: 305-313. 
49) Castilla $P$, Dávalos $A$, Teruel JL, et al.

Comparative effects of dietary supplementation with red grape juice and vitamin $E$ on production of superoxide by circulating neutrophil NADPH oxidase in hemodialysis patients.

Am J Clin Nutr. 2008; 87: 1053-1061.

50) Hodkova M, Dusilova-Sulkova S, Kalousova M, et al. Influence of oral vitamin $\mathrm{E}$ therapy on micro-inflammation and cardiovascular disease markers in chronic hemodialysis patients.

Ren Fail. 2006; 28: 395-399.

51) Boaz M, Smetana $S$, Weinstein $T$, et al. Secondary prevention with antioxidants of cardiovascular disease in endstage renal disease (SPACE): randomised placebo-controlled trial. Lancet. 2000; 356(9237): 1213-1218.

52) Tepel M, van der Giet M, Statz M, Jankowski J, Zidek W.

The antioxidant acetylcysteine reduces cardiovascular events in patients with end-stage renal failure: a randomized, controlled trial.

Circulation. 2003; 107: 992-5. 


\section{TABLES}

TABLE 1

Exclusion Criteria

Age $<18$ years

Age $>80$ years

On maintenance haemodialysis therapy for $<3$ months

Smoking

Known alcohol abuse in previous 12 months

Severe liver disease

Severe uncontrolled cardiac or respiratory disease

Active neoplastic disease

Pregnancy

Breastfeeding

Participating in another clinical trial 


\section{TABLE 2}

Composition of Micronutrient Cocktail

\begin{tabular}{|l|r|}
\hline Supplement & Dose \\
\hline Vitamin C & $60 \mathrm{mg}$ \\
\hline Vitamin E & $10 \mathrm{mg}$ \\
\hline Vitamin K & $65 \mu \mathrm{g}$ \\
\hline & \\
\hline Folic acid & $800 \mu \mathrm{gg}$ \\
\hline Vitamin B2 & $1.6 \mathrm{mg}$ \\
\hline Vitamin B6 & $10 \mathrm{mg}$ \\
\hline Vitamin B12 & $12 \mu \mathrm{gg}$ \\
\hline Vitamin B5 & $1 \mathrm{mg}$ \\
\hline Vitamin B1 & $1 \mathrm{mg}$ \\
\hline & \\
\hline Zinc & $15 \mathrm{mg}$ \\
\hline Copper & $1.5 \mathrm{mg}$ \\
\hline Selenium & $75 \mu$ \\
\hline & \\
\hline
\end{tabular}


TABLE 3a

BASELINE DEMOGRAPHIC AND CLINICAL FEATURES (PROPORTIONS)

\begin{tabular}{|c|c|c|c|c|c|c|c|}
\hline \multirow[t]{2}{*}{ Feature } & \multicolumn{2}{|c|}{ Active Group } & \multicolumn{2}{|c|}{ Placebo Group } & \multicolumn{2}{|c|}{$A / l$} & \multirow{2}{*}{$\begin{array}{c}p \\
\text { value }\end{array}$} \\
\hline & № & $(\%)$ & № & $(\%)$ & № & $(\%)$ & \\
\hline Male & 10 & (56) & 12 & (63) & 22 & (59) & 0.7431 \\
\hline Female & 8 & (44) & 7 & (37) & 15 & (41) & \\
\hline Diabetes $^{a}$ & 7 & (39) & 6 & (32) & 13 & (35) & 0.7374 \\
\hline $\begin{array}{l}\text { Renal } \\
\text { Atherosclerosis }^{b}\end{array}$ & 1 & (6) & 2 & (11) & 3 & (8) & 1.0000 \\
\hline $\begin{array}{l}\text { Significant cardiac } \\
\text { comorbidity }^{c}\end{array}$ & 9 & (50) & 3 & (16) & 12 & (32) & 0.0750 \\
\hline $\begin{array}{l}\text { Significant peripheral } \\
\text { vascular comorbidity }{ }^{d}\end{array}$ & 2 & (11) & 3 & (16) & 5 & (14) & 1.0000 \\
\hline $\begin{array}{l}\text { Cerebrovascular } \\
\text { disease }\end{array}$ & 4 & (22) & 2 & (11) & 6 & (16) & 0.7140 \\
\hline Chronic lung disease & 3 & (17) & 1 & (5) & 4 & (11) & 0.4048 \\
\hline $\begin{array}{l}\text { Inactive neoplastic } \\
\text { disease }\end{array}$ & 0 & (0) & 2 & (11) & 2 & (5) & 0.4865 \\
\hline $\begin{array}{l}\text { All antihypertensive } \\
\text { therapy }\end{array}$ & 13 & (72) & 14 & (74) & 27 & (73) & 1.0000 \\
\hline ACEi or ARB therapy & 8 & (44) & 7 & (37) & 15 & $(41)$ & 0.7431 \\
\hline ESA therapy & 18 & (100) & 19 & (100) & 37 & (100) & 1.0000 \\
\hline $\begin{array}{l}\text { Parenteral iron } \\
\text { therapy }\end{array}$ & 12 & (67) & 17 & (89) & 29 & (78) & 0.1245 \\
\hline Phosphate binders & 14 & (78) & 10 & (53) & 24 & (65) & 0.1704 \\
\hline Vitamin $D$ analogues & 15 & (83) & 10 & (53) & 25 & (68) & 0.0789 \\
\hline Cinacalcet therapy & 2 & (11) & 0 & (0) & 2 & (5) & 0.4872 \\
\hline Statin therapy & 11 & (61) & 12 & (63) & 23 & $(62)$ & 1.0000 \\
\hline
\end{tabular}

\section{TABLE 3a}

*Fisher's exact test

ancluding diabetic nephropathy as primary renal diagnosis.

bas primary renal diagnosis.

'active angina, previous myocardial infarction, previous coronary intervention, episode of heart failure requiring hospital admission.

'active intermittent claudication, ischaemic rest pain, ischaemic ulcers, previous radiological or surgical intervention. 
TABLE 3b

BASELINE DEMOGRAPHIC AND CLINICAL FEATURES (MEANS)

\begin{tabular}{|c|c|c|c|c|c|c|c|}
\hline \multirow[t]{2}{*}{ Feature } & \multicolumn{2}{|c|}{ Active Group } & \multicolumn{2}{|c|}{ Placebo Group } & \multicolumn{2}{|c|}{ All } & \multirow{2}{*}{$\begin{array}{c}p \\
\text { value* }\end{array}$} \\
\hline & Mean & (SD) & Mean & (SD) & Mean & (SD) & \\
\hline Age in Years & 64.50 & $(8.327)$ & 63.25 & (9.199) & 63.83 & (10.14) & 0.7173 \\
\hline Body Mass Index & 26.91 & (5.219) & 26.26 & (4.978) & 26.56 & (4.909) & 0.7301 \\
\hline $\begin{array}{l}\text { Time on Renal } \\
\text { Replacement Therapy } \\
\text { (months) }\end{array}$ & 27.45 & (38.86) & 32.24 & $(60.08)$ & 29.84 & (76.87) & ${ }^{*} 0.8156$ \\
\hline $\begin{array}{l}\text { Equivalent ESA } \\
\text { dosage (units per } \\
\text { week) }\end{array}$ & 6444 & (3240) & 6000 & (2560) & 6216 & (2878) & 0.6453 \\
\hline $\begin{array}{l}\text { Urea Reduction } \\
\text { Ratio }\end{array}$ & 0.7378 & $(0.05231)$ & 0.7363 & $(0.05737)$ & 0.7370 & $(0.05420)$ & 0.9360 \\
\hline$C R P$ & 10.39 & (9.51) & 13.58 & (10.19) & 12.03 & (9.86) & 0.3323 \\
\hline $\begin{array}{l}\text { Total calcium } \\
\text { (mmol/l) }\end{array}$ & 2.351 & $(0.1288)$ & 2.361 & (0.1398) & 2.356 & $(0.1328)$ & 0.8328 \\
\hline $\begin{array}{l}\text { Serum albumin } \\
(\mathrm{g} / \mathrm{I})\end{array}$ & 34.06 & (3.096) & 35.16 & (4.045) & 34.62 & (3.608) & 0.3603 \\
\hline $\begin{array}{l}\text { Phosphate } \\
(\mathrm{mmol} / \mathrm{I})\end{array}$ & 1.492 & $(0.2188)$ & 1.247 & (0.3132) & 1.366 & $(0.2952)$ & 0.0094 \\
\hline $\begin{array}{l}\text { Alkaline } \\
\text { phosphatase }\end{array}$ & 112.8 & (102.3) & 94.42 & (29.42) & 103.4 & (73.93) & **0.4712 \\
\hline PTH & 241.6 & (115.1) & 185.1 & (187.5) & 212.6 & (157.0) & ${ }^{* \star} 0.2750$ \\
\hline $\begin{array}{l}\text { Haemoglobin } \\
(\mathrm{g} / \mathrm{dl})\end{array}$ & 11.71 & (1.461) & 11.57 & $(0.9351)$ & 11.64 & (1.204) & 0.7344 \\
\hline Ferritin & 621.2 & (363.7) & 606.2 & (342.0) & 613.7 & (348.0) & 0.8993 \\
\hline $\begin{array}{l}\text { Transferrin } \\
\text { saturation (\%) }\end{array}$ & 28.50 & (9.476) & 30.11 & (10.69) & 29.31 & (9.991) & 0.6354 \\
\hline $\begin{array}{l}\text { Total cholesterol } \\
(\mathrm{mmol} / \mathrm{I})\end{array}$ & 3.639 & $(0.5658)$ & 3.653 & (0.7389) & 3.646 & $(0.6513)$ & 0.9499 \\
\hline$\beta-2$ microblobulin & 22.64 & (6.939) & 24.93 & (7.225) & 23.78 & (7.011) & 0.4570 \\
\hline FRAP assay*** & 1467 & (236.6) & 1453 & (216.3) & & & NS \\
\hline $\begin{array}{l}\text { Plasma folate } \\
(\mathrm{ng} / \mathrm{ml})\end{array}$ & 5.55 & (4.42 & 6.29 & (2.82) & & & NS \\
\hline $\begin{array}{l}\text { Whole blood } \\
\text { folate }(\mathrm{ng} / \mathrm{ml})\end{array}$ & 17.05 & (11.71) & 19.09 & (11.76) & & & NS \\
\hline
\end{tabular}

*Student's t-test

**employing Welch's correction

***Ferric Reducing Ability of Plasma 


\section{LEGENDS FOR FIGURES}

Figure 1: Baseline Superoxide Dismutase Levels

Figure 2: Change in Superoxide Dismutase in Control $(p=0.0443)$ and Active ( $p=0.3083)$ Groups (Student's t-test).

Figure 3: Baseline Glutathione Peroxidase Levels

Figure 4: $\quad$ Change in Glutathione Peroxidase levels in Control $(p=0.1546)$ and Active ( $p=0.0123)$ Groups (Student's t-test). 


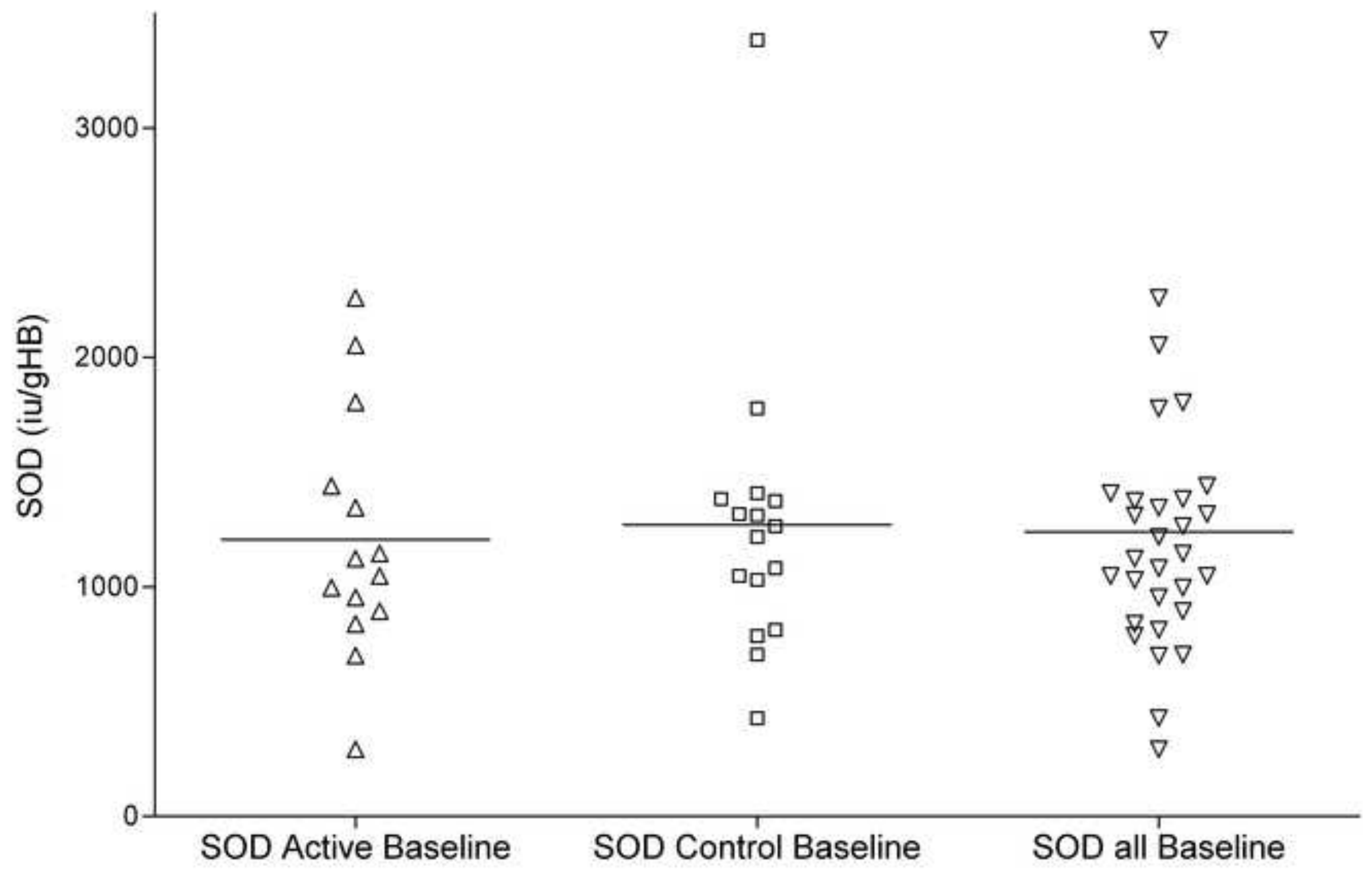

Figure 1 


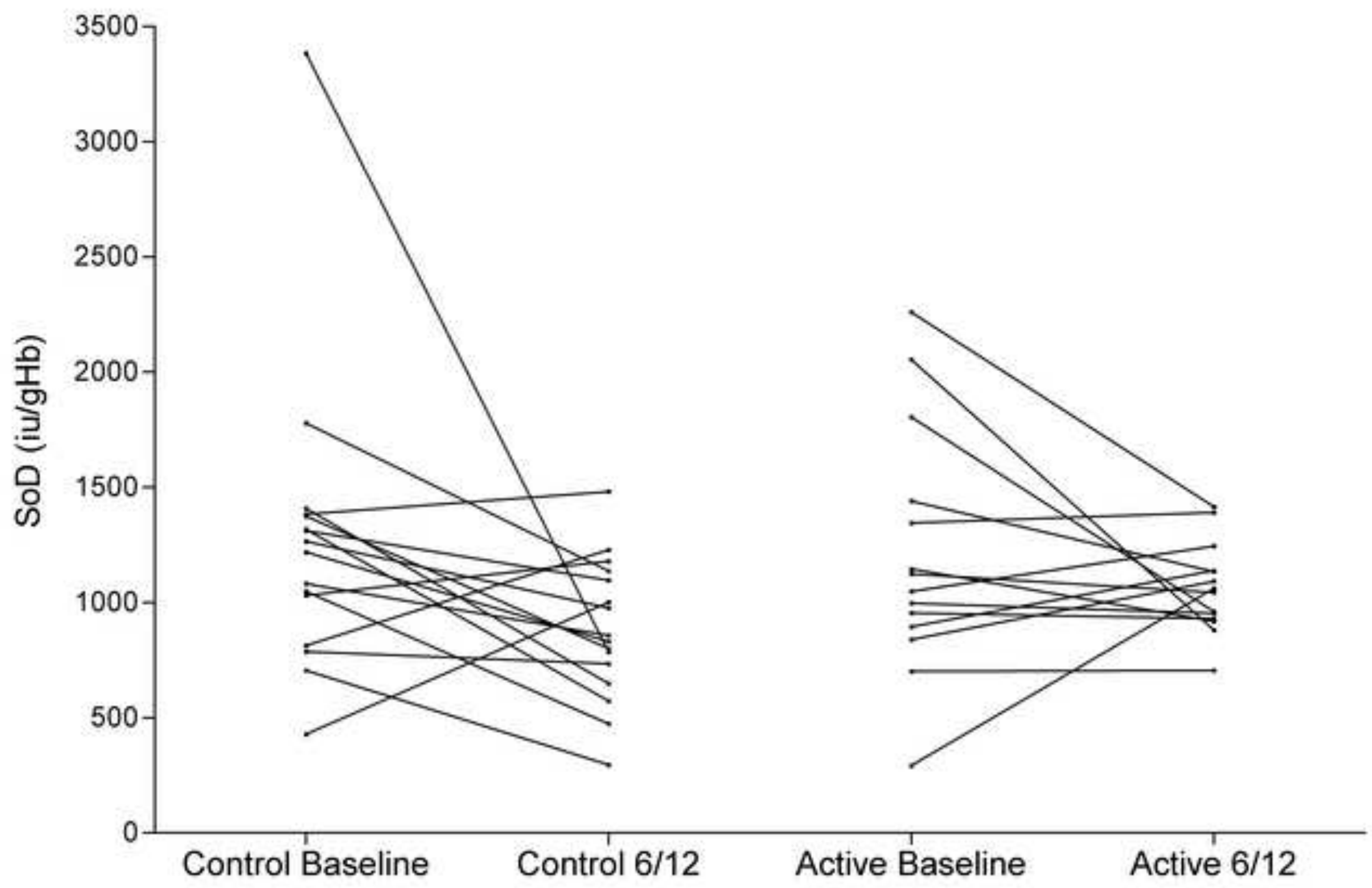

Figure 2 


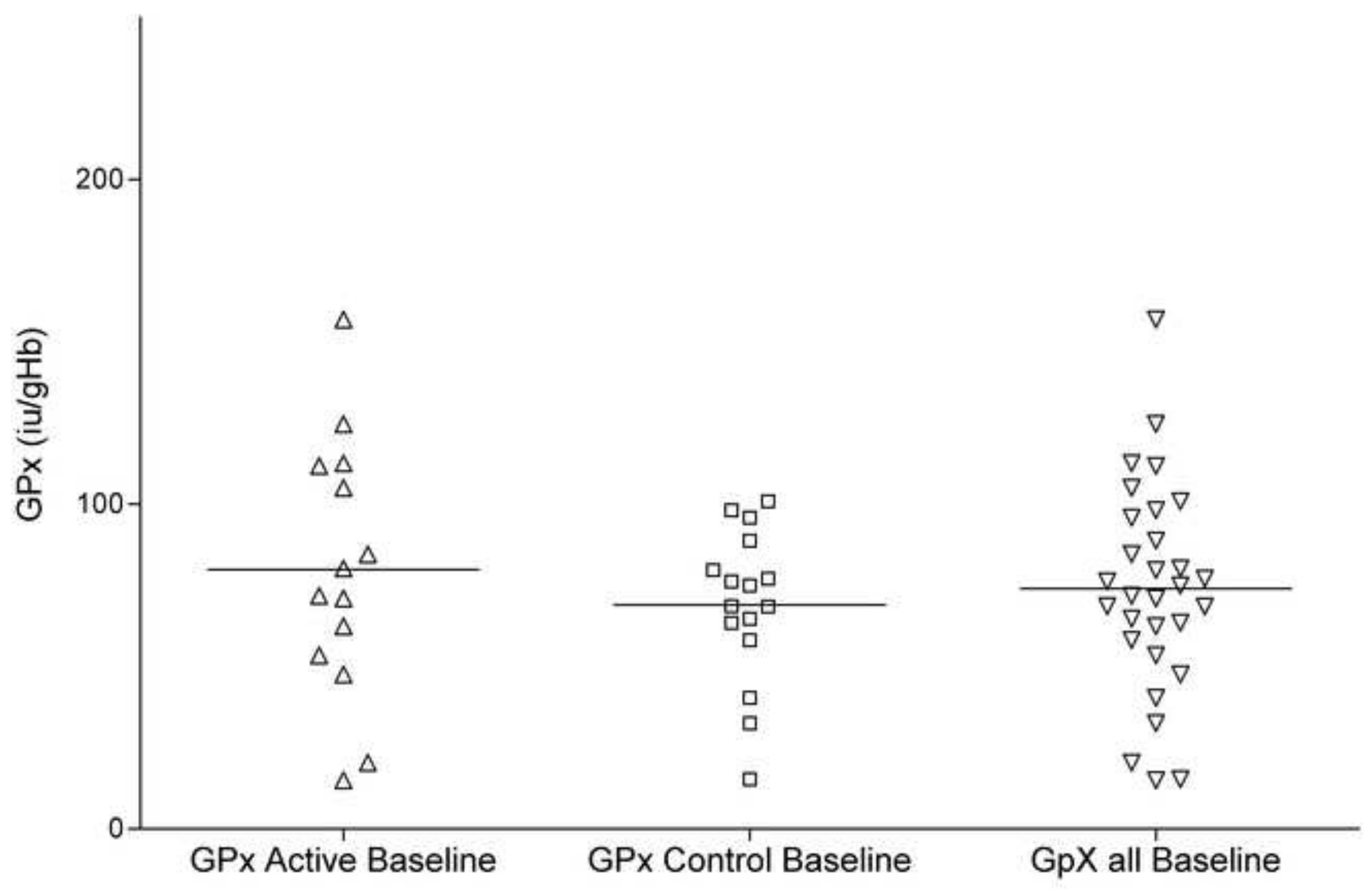

Figure 3 


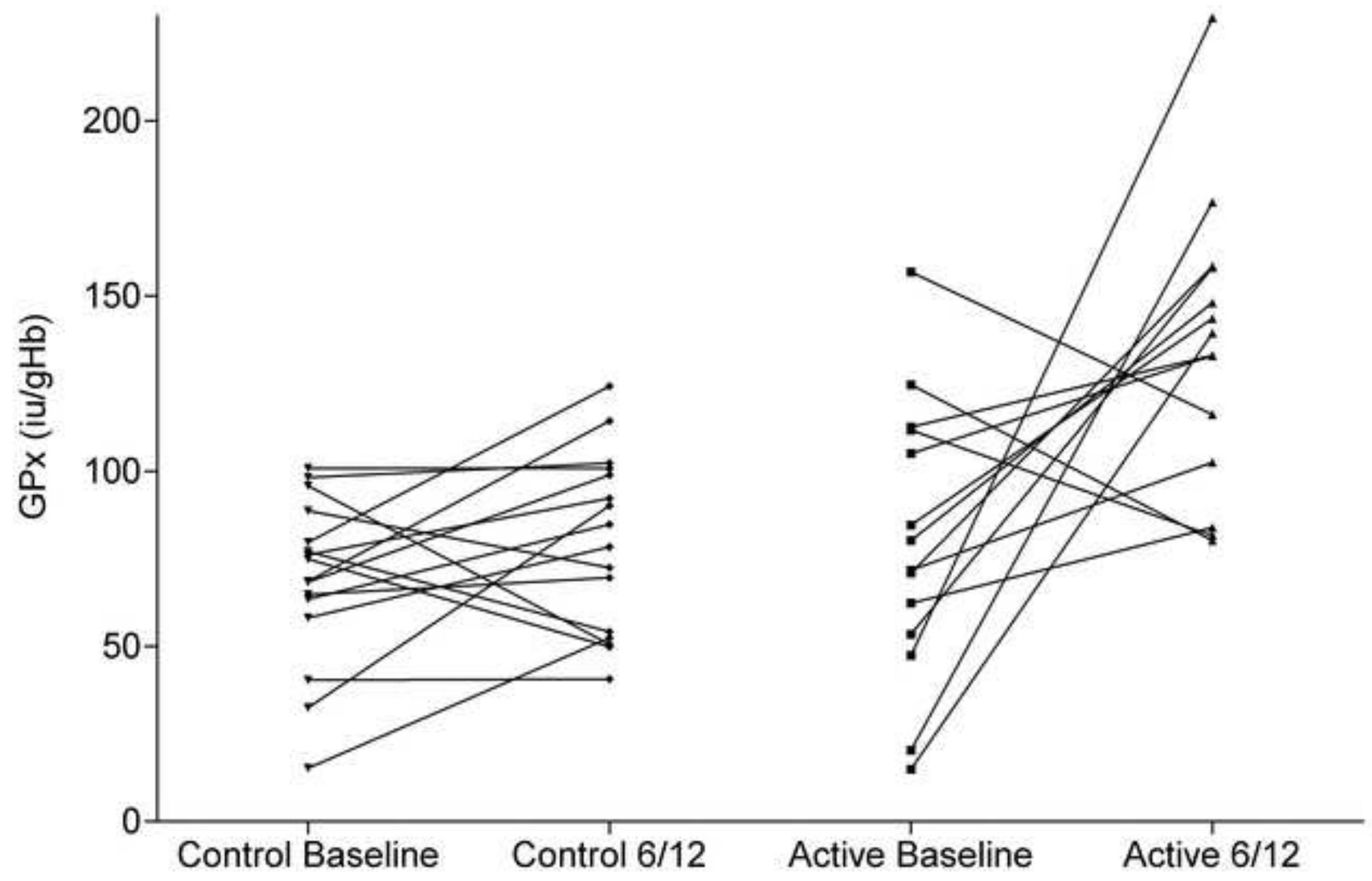

Figure 4 


\section{Renal Unit \\ Tyrone County Hospital \\ Omagh \\ $\mathrm{N}$ Ireland \\ BT79 OAP}

Francesca Mallamaci, MD

Editor-in-Chief, Journal of Nephrology

Consiglio Nazionale delle Ricerche (CNR-IBIM)

Epidemiologia Clinica e Fisiopatologia delle Malattie Renali e dell'Ipertensione Arteriosa \& Unità Operativa di Nefrologia, Dialisi e Trapianto ( $6^{\circ}$ piano)

Ospedali Riuniti

Via Vallone Petrara - 89100 Reggio Calabria - Italy

$19^{\text {th }}$ October 2011

Dear Dr Mallamaci,

I hope you might be able to consider the attached electronic script entitled "Micronutrient supplementation in maintenance haemodialysis patients enhances activity of antioxidant enzymes" as a candidate for publication in $J$ Nephrol.

As a previous invited contributor to $J M$ I have formed a high regard for the quality and impact of the journal and believe that it would be an ideal forum for publication of this original and carefully conducted RCT. The strongly significant results of the trial will contribute to the growing picture of amelioration of oxidative stress in haemodialysis patients.

PJG collaborated in the conception and design of the study, supervised the clinical aspects of the project, analysed the data, prepared the draft manuscript and approved the final version.

MHF collaborated in the conception and design of the study, supervised the analytical aspects of the project, reviewed and contributed to revision of the manuscript and approved the final version.

TAM recruited the subjects, was responsible for the direct conduct of the study, reviewed and contributed to revision of the manuscript and approved the final version

The study was performed in accordance with full ethical approval by ORECNI (the Office for Research Ethics Committees of Northern Ireland) and the 
Research Governance Committee of the Western Health and Social Care Trust.

We can confirm that the results presented in this paper have not been published previously in whole or part, except in abstract form.

Yours sincerely,

Dr Peter Garrett

Dr Mary Hannon-Fletcher

Ms Twyla Moffitt. 